\title{
COURSE DESCRIPTION AND SYLLABUS: RELIGION 104, "INTRODUCTION TO JUDAISM" EMORY UNIVERSITY, 1989-90
}

\author{
Laura Levitt
}

\begin{abstract}
Laura Levitt is a Ph.D. candidate in Constructive Jewish Theology at Emory University, where she will also receive a certificate in Women's Studies. Her dissertation, "Identity/ies: Rethinking Jewish Feminist Theory and Practice," uses the tools of Feminist and Critical Theory to address the diversity of Jewish Feminist experience. She has an M.A. degree from Hebrew Union College-JIR in Modern Jewish Thought and an A.B. in Religious Studies from Brown University. In January 1992, Ms. Levitt will become an Assistant Professor of Jewish Studies in the Department of Religion at Temple University, where she will teach courses in Jewish Studies and Feminist Theory.
\end{abstract}

\section{Rationale}

Traditionally in the Jewish community learning has been a communal activity. When I put together my course "Introduction to Judaism," I wanted it to reflect this value. I also wanted to do this in a critical way which would take into account the fact that Jewish women were excluded from this process. Given this history, I ask my students to enter into worlds which on the one hand seem to offer much hope and much promise for contemporary practice. On the other hand, I ask them to do so with their eyes wide open to the asymmetrical power relationship which often hold up these very systems. Maintaining these contradictory positions is uncomfortable, but it is also honest. By doing both, I ask my students to engage in a kind of critical practice. Mine is a feminist critical practice which is informed by what Elisabeth Schussler Fiorenza calls an "ethic of accountability." I want to teach my students to be accountable for their positions vis-a-vis the tradition. I want them to be responsible for the political, social, and moral implications of course readings. This is especially important given the power of "Torah," both Oral and Written, in shaping Jewish communal values and practices.

Students are asked to take seriously the implications of their own interpretations. This is the challenge of the course. I hope to teach students to see not only what a text says on its surface but to think, as Schussler 
Fiorenza suggests, about the rhetorical situation in which these statements were and are still being made. For example, as feminist scholars like Bernadette Brooten and others have suggested, just because a text like the Mishnah may not mention women in the public sphere does not necessarily mean that women did not hold positions of communal authority at the time this text was written. Thus, the Mishnah needs to be read with a "hermeneutic of suspicion," for it may not be reflecting social practices as much as it may be prescribing them.

This critical practice is reinforced in the requirements for the course. Students are expected to work together in small groups, whether outlining questions to be turned in as part of an exam or working on group projects. In addition to this, students are required to use gender-neutral language except when referring to gender-specific issues or materials. Finally in terms of accountability, students are each required to attend and critique two Jewish services. In these papers students must be clear and up-front about their experiences, whether they are non-Jews going to a Jewish service for the first time or Reform Jews going to an Orthodox service. In so doing, students are asked to take responsibility for their positions and not hide behind a cloak of objectivity. In this course there is no such thing.

\section{Syllabus for the Course}

\section{Religion 104: Introduction to Judaism}

MWF 11-12:00

Spring 1990, Emory University

Instructor: Laura Levitt

Office Hours: by appointment

This course will be an introduction to Jewish history and the diverse faces of Judaism. Students will be exposed to a wide range of Jewish experience from the biblical period to the present. Given the diversity of these experiences, students will be encouraged to develop and articulate their own answer to the question: What is Judaism in various historical, cultural, political, and economic contexts?

Method: In this course, students will be exposed to historical material as well as a wide range of religious, cultural, and political artifacts, generally the texts of specific Jewish communities. Students will learn to read, interpret, and critically assess these documents in class discussions, group projects, and papers, as well as essay exams. 
Texts:

Required:

Photocopied Readings

Holtz (ed.), Back to the Sources

Neusner, The Way of Torah

Seltzer, Jewish People, Jewish Thought

Hebrew Bible, any standard translation (recommend JPS, Tannach)

Requirements:

1. Class Participation $20 \%$

- preparation, contribution to class discussion, attendance

- quizzes on reading at instructor's discretion

2. Short papers $30 \%$

- two Service Critiques, one page each

- two 3-page papers to be written in Havruta (small groups of 2 or 3 students)

3. Exams $50 \%$

- midterm essay exam

- final essay exam

\section{Introduction: What is Judaism?}

Jan. 17: Introduction of course, preliminary observations

19: What is Judaism? What is a "mythic structure" and how does it function? What are the key elements of the "Jewish structure" ? What do you think of Neusner's definition? What are its merits and what are its drawbacks? How does it compare with your own definition? Read: Neusner, The Way of Torah, introduction, pp. 2-8 and pp. 42-49.

\section{The Biblical Period}

A. Introduction, methodology, and history

22: The Ethics of Interpretation. What is an Ethics of Accountability? Is this necessarily a "rational" or "objective" approach? Why or why not? Read: Schussler-Fiorenza, "The Ethics of Interpretation: De-centering Biblical Scholarship," photocopied.

24: The Biblical Period, pre-history. Read: Seltzer, pp. 34-43 and Lerner, Chapter 9, "The Covenant," photocopied. What does Lerner claim the covenant is all about? To whom does it pertain and why? What does Seltzer say? 
26: Texts. How do/did "traditional Jews" study texts? What is a "text"? What is the difference between studying and reading according to this essay? What is a Havruta? Read: Holtz, "Introduction: Reading Jewish Texts," pp. 11-29.

B. The Bible

29: Genesis, biblical narrative, Gen. 2-3. Read: Holtz, pp. 31-81. For class discussion read carefully and be prepared to discuss pp. 52-62 and Bal reading, photocopied. Who is created first? Who is "HaAdam" of "Clod"?

31: Jewish Peoplehood. Read: Genesis 12:1-10, "Lech Lecha," Silberman translation, photocopied. Prepare your own questions on the readings. What is the text all about? Are there any passages in the text that are unclear? Which ones? Why? Read also: Holtz, pp. 31-52.

Feb. 2 Biblical Law, Kashrut, and Holiness. Read: Douglas reading, photocopied. Be prepared to discuss Douglas material in class. For background read: Holtz, pp. 83-104. What is holiness according to Douglas? What makes something pure? What does one do to be "holy"? Why keep kosher?

5: The Kingship, David and Bathsheba. Read: II Samuel 11-12, and M. Bal, pp. 28-9, Lethal Love, to be handed out in class.

7: Prophets, Second Isaiah. Read: Seltzer, focus on pp. 122-128; Isaiah 40-66. For background read: Seltzer, pp. 108-11.

III. Hellenism, the Second Temple Period until 70 C.E.

9: Hellenism. Read: Seltzer, pp. 155-164, Daniel 7-12.

12: The Second Temple Period, different sects, Sadducees, Pharisees, Essenes, responses to destruction, 70 C.E. Read: Seltzer, pp. 178-194, pp. 213-224.

14: Christianity in relation to Judaism, especially Pharisaic Judaism (the Rabbis). Read: Neusner, The Way of Torah, pp. 29-39; Reuther, photocopied. Guest lecture: Rick Voyles.

\section{Rabbinic Judaism}

A. Halacha

16: The Mishnah. Read: focus on Feinstein, pp. 8-15, and Neusner, from Invitation to the Talmud, pp. 35-43, photocopied. For background read: Seltzer, pp. 260-65. 
19: Talmud, how does it work? What does it look like? Read: Holtz, pp. 129-143, 163-175; Neusner, from Learn Talmud, pp. 6-15 photocopied; Seltzer, pp. 265-267.

21: Mishnah Yoma 8:9. Read: Neusner, from Leam Talmud, pp. 124-140. Take notes with your Havruta and be prepared to argue your group's understanding of the passage in class. Do you agree with Neusner? Why or why not?

23: Women in the Mishnah. Read: Romney Wegner, "Tragelaphos: the Anomaly of Women in the Mishnah." pp. 160-172, photocopied. Think about this in terms of the Douglas reading we did earlier. Why are women "dangerous," to whom and for whom are they "dangerous"?

26: Halacha and Aggadah, the multiple faces of Rabbinic Literature. See Layers of Jewish Law chart, photocopied; read: Holtz, pp. 177-211.

B. Aggadah, Midrash, more Rabbinic textual praxis

28: Exegetical vs. Homiletical Midrash, Midrashic Process. Work with your Havruta and prepare one page of the Maggid reading. Read: from portion of the Haggadah, photocopied. The homiletic move: How do the rabbis jump from topic to topic? What are the links that you see, what connections do you see between the various "digressions"? What is the "maggid" section of the haggadah?

C. Rabbinic Judaism and other Judaisms in Late Antiquity

March 2: Mythic structure: Theology and Liturgy. Read: Holtz, pp. 403-421; Neusner, The Way of Torah pp. 42-60. How does the liturgy relate to Neusner's mythic structures? What does all of this tell us about the relationship between the Jewish people and their God according to the Rabbis and their heirs?

5: Other Judaisms in Late Antiquity, artistic evidence. Synagogal art, Bet Alpha and Dura Europas, slides.

\section{Medieval Judaisms}

7: Jews under Islam. Read: Seltzer, pp. 325-350, getting the people, places, and dates straight.

9: Apologetics and polemics: Philosophy, Christianity, Islam, and Judaism. HaLevi's literary strategy. Read: Yehudah HaLevi, from The Kuzari, Book I, photocopied 


\section{SPRING BREAK}

19: Jews in Medieval Christian Europe. Read: Seltzer, pp. 350-372.

21: Kabbalah, Jewish Mysticism. Guest lecture, Dr. David Blumenthal. Read: Blumenthal Mysticism reading, photocopied.

23: Jews in Poland and Lithuania, the late Medieval period, Ashkenazi Judaisms. Read: Seltzer, pp. 474-495.

\section{Emancipation: The Modern Period}

26: Emancipation: Jews in Western Europe, The Promises of Liberalism. Read: Chazen/Raphael, pp. 1-31; read carefully pp. 14-31 for class, photocopied. What concession were Jews living in France required to make to become French citizens?

\section{8: MIDTERM}

30: The Reformers, Reform, Modern Orthodoxy, and Conservative Judaisms. Read: Chazen/Raphael, pp. 45-52 and MendesFlohr/Reinharz, photocopied.

April 2: Liberalism's mixed blessings. Read: Chazen/Raphael on Dreyfus Affair, pp. 91-115, photocopied.

4: Zionism, Pinsker and Herzl. Read: Chazen/Raphael, pp. 160-174 and Hertzberg on Herzl, photocopied.

6: Eastern European Jewry Between the Wars, WWI and WWII. Film: "Image Before My Eyes.”

\section{Post-Modern Period}

9: The Shoah. Read: Des Pres, pp. 51-57, 149-177; and Klepfisz "Basherit," photocopied. (This is difficult material. If you cannot be in class students will be expected to write a one-page response to the Des Pres reading.)

11: Passover Second Seder, no class.

13: Responding to the Holocaust. Read: David Blumenthal's Psalm 44 , photocopied, and be prepared to discuss it in class. How is this a Jewish theological response? Think about both form and content. How does Blumenthal's method relate to Rabbinical textual practice?

16: Myth of Holocaust and Redemption, part one, 1967 to the presnet (1982?). Read: Neusner, from Stranger at Home, pp. 61-81, photocopied. 
18: Part two, Israel as "Redemption"? Read: Neusner, from Stranger at Home, pp. 99-126, photocopied.

20: Israel and the problematics of Myth. Read: Hareven, "The First Forty Years," pp. 3-28, photocopied.

23: Towards a Jewish Liberation Theology, Political Power and the Scarred, Israel and American Jewry. Read: Levitt, photocopied.

25: The Present Situation, The Intifada and the Tension in Israel, What to do with Anger? Read: Ezrahi, "Eyeless in Gaza" and Kahane, NYT editorial, photocopied.

27: Feminist Theologies and the Question of Midrash. Read: Plaskow, photocopied.

30: Issues for Post-Modern Jews, Questions of Identity, putting the pieces together.

\section{Photocopied Readings: Table of Contents}

1. Vocabulary for Jewish Living. This is to be used as a reference guide for those unfamiliar with the terrain. It will be especially useful for writing Service Critiques (see also the glossary in Neusner's The Way of Torah).

2. Schussler Fiorenza, Elizabeth. "The Ethics of Interpretation: DeCentering Biblical Scholarship." SBL, Journal of Biblical Literature, Vol. 107, No. 1 (March 1988), pp. 3-17.

3. Lerner, Gerda. The Creation of Patriarchy. New York: Oxford University Press, 1986, pp. 180-198.

4. Bal, Mieke. Lethal Love: Feminist Literary Readings of Biblical Love Stories. Bloomington: Indiana University Press, 1987, pp. 109-130.

5. Douglas, Mary. Purity and Danger: An Anabysis of the Concepts of Pollution and Taboo. London: ARK Paperbacks, 1984, pp. 41-57.

6. Pentateuch with Rashi's Commentary, Genesis. Jerusalem: Silberman Family 1973, pp. 48-50; Lech Lecha, Gen. 12:1-8.

7. Reuther, Rosemary. Faith and Fratricide: The Theological Roots of AntiSemitism. New York: Seabury Press, 1979, pp. 95-116.

8. Feinstein, Morley. The Jewish Law Review, Vol. 1.1: The Mishnah on Damages. Los Angeles, CA: Torah Orah, pp. 8-15.

9. Neusner, Jacob. Invitation to the Talmud: A Teaching Book. New York: Harper and Row, 1973, pp. 35-43. 
10. - Leam Talmud. New York: Behrman House, Inc., 1979, pp. 6-15; pp. 124-140.

11. Romney Wegner, Judith. "Tragelaphos: The Anomaly of Women in the Mishnah,” Judaism, Vol. 36, No. 3 (Spring 1988), pp. 160-172.

12. Layers of Jewish Law Chart, taken from Grishaver, Joel Lurie, Bet Din: The Jewish People's Court, Student Casebook. Los Angeles, CA: Torah Aura Productions, pp. 10-11.

13. The Maggid section of the Passover Haggadah, taken from Passover Haggadah, The Feast of Freedom, The Rabbinical Assembly, 1982, pp. 30-77 (prepare one full page in Havruta only).

14. HaLevi, Yehudah. The Kuzari: An Argument for the Faith of Israel. New York: Schocken Books, 1964, pp. 35-50.

15. Blumenthal, David. Understanding Jewish Mysticism: A Source Reader. New York: Ktav, 1987, pp. xv-xvii, 185-191.

16. Chazen, Robert and Marc L. Raphael. Modern Jewish History: A Source Reader. New York: Schocken Books, 1969, pp. 1-31; pp. 45-52; pp. 91-115.

17. Mendes-Flohr, Paul and Jehuda Reinharz. The Jew in the Modem World. New York: Oxford University Press, 1980, pp. 173-81.

18. Hertzberg, Arthur, ed. The Zionist Idea: A Historical Analysis and Reader. New York: Atheneum, 1969, pp. 201-226.

19. Des Pres, Terrence. The Survivor: An Anatomy of Life in the Death Camps. New York: Oxford University Press, 1987. "Excremental Assault," pp. 51-71; "Us and Them," pp. 149-177.

20. Klepfisz, Irena. "Basherit," from Keeper of Accounts, Watertown, MA: Persephone Press, Inc., 1982, pp. 74-76.

21. Blumenthal, David. "Psalm 44, Translation and Multivocal Commentary," unpublished manuscript. Atlanta: Emory University, Fall 1988.

22. Neusner, Jacob. Stranger at Home, "The Holocaust," Zionism, and American Judaism. Chicago: University of Chicago Press, 1981, pp. 61-81; pp. 99-126.

23. Hareven, Shulamith. "The First Forty Years," The Jerusalem Quarterly, No. 48 (Fall 1988), pp. 3-28. 
24. Ezrahi, Sidra. "Eyeless in Gaza," Tikkun, Vol. 3, No. 3 (May/June 1988), pp. 48-50.

25. Kahane, Meir. "The 'Guilt' of Jews Threatens Israel," New York Times, April 7, 1989.

26. Levitt, Laura. "Political Power: Learning a New Jewish Theological Vocabulary," Paradigms (Winter 1990).

27. Plaskow, Judith. "Standing at Sinai: Jewish Memory from a Feminist Perspective," Tikkun, Vol. 1, No. 2 (1986), pp. 28-34. 